\title{
Cerebrospinal Fluid Profile of Amyloid $\beta$ Peptides in Patients with Alzheimer's Disease Determined by Protein Biochip Technology
}

\author{
Alessia S. Maddalena ${ }^{a}$ Andreas Papassotiropoulos ${ }^{a}$ \\ Charo Gonzalez-Agosti ${ }^{a}$ Andri Signorella Thomas Hegi ${ }^{b}$ Thomas Pasch ${ }^{b}$ \\ Roger M. Nitsch ${ }^{a}$ Christoph Hock ${ }^{a}$ \\ aDivision of Psychiatry Research and bInstitute of Anesthesiology, University of Zürich, Zürich, Switzerland
}

\section{Key Words}

Alzheimer's disease $\cdot \beta$-Amyloid · Cerebrospinal fluid ·

Protein biochip . ELISA

\begin{abstract}
Amyloid- $\beta$ peptides $(A \beta)$ are major components of amyloid plaques in the Alzheimer's disease (AD) brain and have been proposed as diagnostic markers in cerebrospinal fluid (CSF). A $\beta$ derived from brain may be processed into fragments before emerging in CSF. Therefore, we determined mass profiles of $A \beta$ peptides in CSF of patients with $A D$ and age-matched healthy control subjects (CTR) by using protein biochip technology. $A \beta$ peptides were captured on the chip surfaces (spots) by the specific monoclonal antibody $6 \mathrm{E} 10$ and were then analyzed by integrated surface-enhanced laser desorption and ionization time-of-flight mass spectrometry (SELDI-TOF-MS). We found $A \beta$ species with mean molecular masses at 1,583.3 $\mathrm{Da}$ (corresponding to $A \beta_{2-14}$ ), 2,068.5 Da $\left(A \beta_{1-17}\right), 2,166.4 \mathrm{Da}\left(\mathrm{A} \beta_{1-18}\right), 3,676.6 \mathrm{Da}$ $\left(A \beta_{1-33}\right), 3,789.4 \mathrm{Da} \quad\left(A \beta_{1-34}\right), 4,076.9 \mathrm{Da} \quad\left(\mathrm{A} \beta_{1-37}\right)$, 4,134.0 $\mathrm{Da}\left(\mathrm{A} \beta_{1-38}\right), 4,233.3 \mathrm{Da}\left(\mathrm{A} \beta_{1-39}\right), 4,332.4 \mathrm{Da}$ $\left(A \beta_{1-40}\right)$ and 4,516.8 $\mathrm{Da}\left(A \beta_{1-42}\right)$ in both $A D(n=24)$ and CTR ( $n=24$ ) subjects. $A \beta_{1-38}$ appeared to be a major $A \beta$ species in human CSF along with $A \beta_{1-40}$. Quantitation
\end{abstract}

revealed that CSF levels of $A \beta_{1-38}$ were significantly decreased in AD as compared to CTR subjects. The CSF profile of $A \beta$ peptides may be used for diagnostic and therapeutic purposes in clinical studies.

Copyright $\odot 2004$ S. Karger AG, Base

\section{Introduction}

$\beta$-Amyloid $(\mathrm{A} \beta)$ deposits, along with neurofibrillary tangles, are the major histopathological hallmarks of Alzheimer's disease (AD). The predominant protein component of $A \beta$ plaques are strongly aggregating peptides with an approximate molecular mass of $4 \mathrm{kDa}$ [1-3]. Whereas $A \beta_{42}$ is the major component of $A \beta$ plaques, $A \beta_{40}$ is mostly found in vascular amyloid of brain blood vessels [4]. Cerebrospinal fluid (CSF) levels of $A \beta_{42}$ measured by ELISA were shown to be lower in AD patients as compared to controls [for a review, see 5], while conflicting results were reported from $A \beta_{40}$ measurements [6-12].

A number of reasons explaining the conflicting data were discussed, including heterogeneity of the patient sample and limitations of the ELISA method used, which do not display the various fragments of peptides captured by the monoclonal antibodies.

\begin{tabular}{ll}
\hline KARGER & ( 2004 S. Karger AG, Basel \\
1660-2854/04/0015-0231\$21.00/0 \\
$\begin{array}{l}\text { Fax +4161306 12 34 } \\
\begin{array}{l}\text { E-Mail karger@karger.ch } \\
\text { www.karger.com }\end{array}\end{array}$ & $\begin{array}{l}\text { Accessible online at: } \\
\text { www.karger.com/ndd }\end{array}$
\end{tabular}

Christoph Hock, MD

Division of Psychiatry Research

Psychiatric University Hospital Zürich, Lenggstrasse 31

CH-8029 Zürich (Switzerland)

Tel. +41 44384 2271, Fax +41 44384 2275, E-Mail chock@bli.unizh.ch 


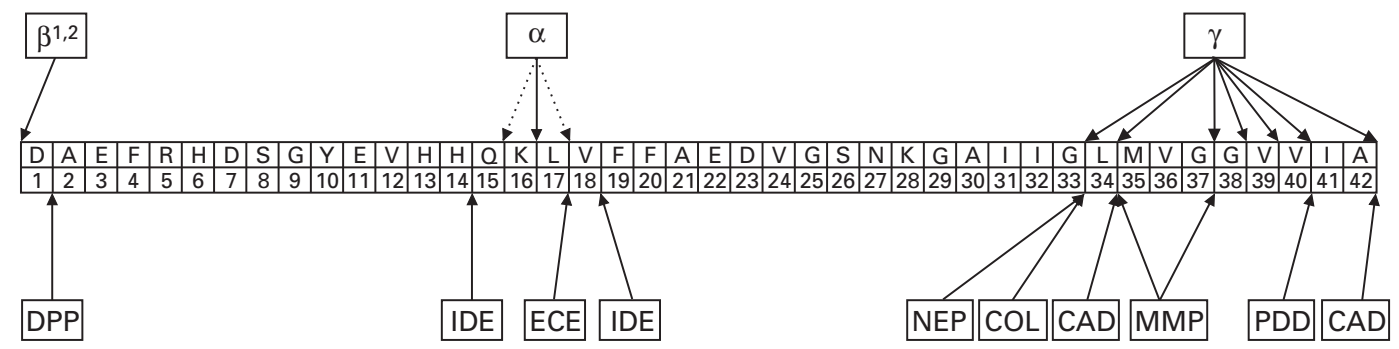

Fig. 1. Potential cleavage sites of $A \beta$ peptide: secretases and putative proteases. $\alpha=$ Alpha secretase; $\beta=$ beta secretase (BACE 1 and 2); $\gamma$ = gamma secretase; DPP = dipeptidyl peptidase; IDE = insulin-degrading enzyme; ECE = endothelinconverting enzyme 1 (ECE-1); $\mathrm{NEP}=$ neprilysin; $\mathrm{COL}=$ collagenase; $\mathrm{MMP}=$ matrix metalloproteinase 9 (MMP-9); $\mathrm{CAD}=$ cathepsin $\mathrm{D} ; \mathrm{PDD}=$ peptidyl dipeptidase.

To clarify the patterns of $A \beta$ peptides present in CSF we determined mass profiles of $A \beta$ in patients with $A D$, as well as in age-matched healthy control subjects (CTR) by using a protein biochip technology (SELDI, Ciphergen) [13-17].

\section{Subjects and Methods}

\section{Subjects}

A diagnosis of probable AD was made according to NINCDSADRDA criteria [18] as well as ICD10 [19]. The clinical workup included neuropsychological testing, MRI scans and routine CSF investigations. The mean Mini-Mental State Examination (MMSE) scores were $21 \pm 5.8(\mathrm{SD})$ in the $\mathrm{AD}$ group $(\mathrm{n}=24)$. The mean age (SD) was $71.2 \pm 9$ years; there were 10 females and 14 males. Healthy CTR $(\mathrm{n}=24)$ were recruited among cognitively intact patients undergoing spinal anesthesia before surgical intervention. The mean age was $65.7 \pm 12$ years; there were 8 females and 16 males. The study was approved by the local ethics committee and subjects gave written informed consent prior to the investigation. CSF was obtained by lumbar puncture, aliquoted, immediately frozen at the bedside $\left(-80^{\circ} \mathrm{C}\right)$ and freshly thawed prior to the analyses.

\section{Protein Biochip Analysis}

Capturing A $\beta$ peptides from CSF was done on SELDI Protein G-coated (PG20) ProteinChip ${ }^{\circledR}$ Arrays (Ciphergen Biosystems, Palo Alto, Calif., USA). Like PS20 ProteinChips, PG20 ProteinChip Arrays contain an epoxy surface which covalently reacts with amine and thiol groups and allows precoupling with recombinant Protein G. The specific monoclonal antibody $6 \mathrm{E} 10$ against $\mathrm{A} \beta$ epitope $1-17$ (Signet Pathology Systems, Dedham, Mass., USA) was first purified on Protein $G$ columns [ImmunoPure Protein $(G)$ IgG Purification Kit, Pierce Biotechnology, Rockford, Ill., USA] and then added $(2 \mu \mathrm{l}$ of $0.2 \mathrm{mg} / \mathrm{ml}$ ) on the microspots followed by incubation in a humidity chamber at room temperature for $1 \mathrm{~h}$. Antibody solution was removed and the chip array was washed once in bulk with $8 \mathrm{ml}$ phos- phate buffer saline (PBS, pH 7.4) containing $0.5 \%(\mathrm{v} / \mathrm{v})$ Triton X-100 for $10 \mathrm{~min}$, then twice in bulk with $8 \mathrm{ml}$ PBS for $5 \mathrm{~min}$. The spots were coated with $5 \mu \mathrm{l}$ crude CSF and incubated in a humidity chamber at $4{ }^{\circ} \mathrm{C}$ overnight. CSF was removed and spots were washed; first in bulk with $8 \mathrm{ml}$ PBS (pH 7.4) containing $0.5 \%(\mathrm{v} / \mathrm{v})$ Triton X-100 for $10 \mathrm{~min}$, then washed in bulk twice with $8 \mathrm{ml}$ PBS for $5 \mathrm{~min}$, and finally rinsed with $1 \mathrm{~m} M$ HEPES buffer. $\alpha$-Cyano-4-hydroxy cinnamic acid (CHCA) was dissolved in $50 \%(\mathrm{v} / \mathrm{v})$ acetonitrile, $0.1 \%$ (v/v) trifluoroacetic acid. After drying, a 1:5 diluted solution of CHCA was added to the spots $(0.5 \mu \mathrm{l})$ and mass identification was made by 100 averaged shots in a Ciphergen SELDI Protein Biology System II (PBS II). All data were normalized against a common matrix peak. Signal to noise $(\mathrm{S} / \mathrm{N})$ ratios above 2.5 were considered to be sufficient to submit the data to statistical analysis.

\section{Statistical Analysis}

Group comparisons were done by nonparametric Mann-Whitney $\mathrm{U}$ tests. Statistical significance was assumed at $\mathrm{p}<0.05$.

\section{Results}

We found CSF species of $A \beta$ peptides with mean molecular masses at $1,583.3 \mathrm{Da}$ (corresponding to $\left.\mathrm{A} \beta_{2-14}\right), 2,068.5 \mathrm{Da}\left(\mathrm{A} \beta_{1-17}\right), 2,166.4 \mathrm{Da}\left(\mathrm{A} \beta_{1-18}\right)$, 3,676.6 $\mathrm{Da}\left(\mathrm{A} \beta_{1-33}\right), 3,789.4 \mathrm{Da}\left(\mathrm{A} \beta_{1-34}\right), 4,076.9 \mathrm{Da}$ $\left(\mathrm{A} \beta_{1-37}\right), 4,134.0 \mathrm{Da}\left(\mathrm{A} \beta_{1-38}\right), 4,233.3 \mathrm{Da}\left(\mathrm{A} \beta_{1-39}\right)$, 4,332.4 $\mathrm{Da}\left(\mathrm{A} \beta_{1-40}\right)$ and 4,516.8 $\mathrm{Da}\left(\mathrm{A} \beta_{1-42}\right)$ in both $\mathrm{AD}$ $(\mathrm{n}=24)$ and CTR $(\mathrm{n}=24)$ subjects (fig. 1a). Mass detection showed high accuracy with minimal intersample deviation and corresponded well to calculated peptide masses (table 1, fig. 1).

$\mathrm{A} \beta_{1-38}$ and $\mathrm{A} \beta_{1-40}$ were the most prominent $\mathrm{A} \beta$ species in CSF and fulfilled the requirement of an $\mathrm{S} / \mathrm{N}$ ratio over 2.5 for quantitation (fig. 2a, b). 


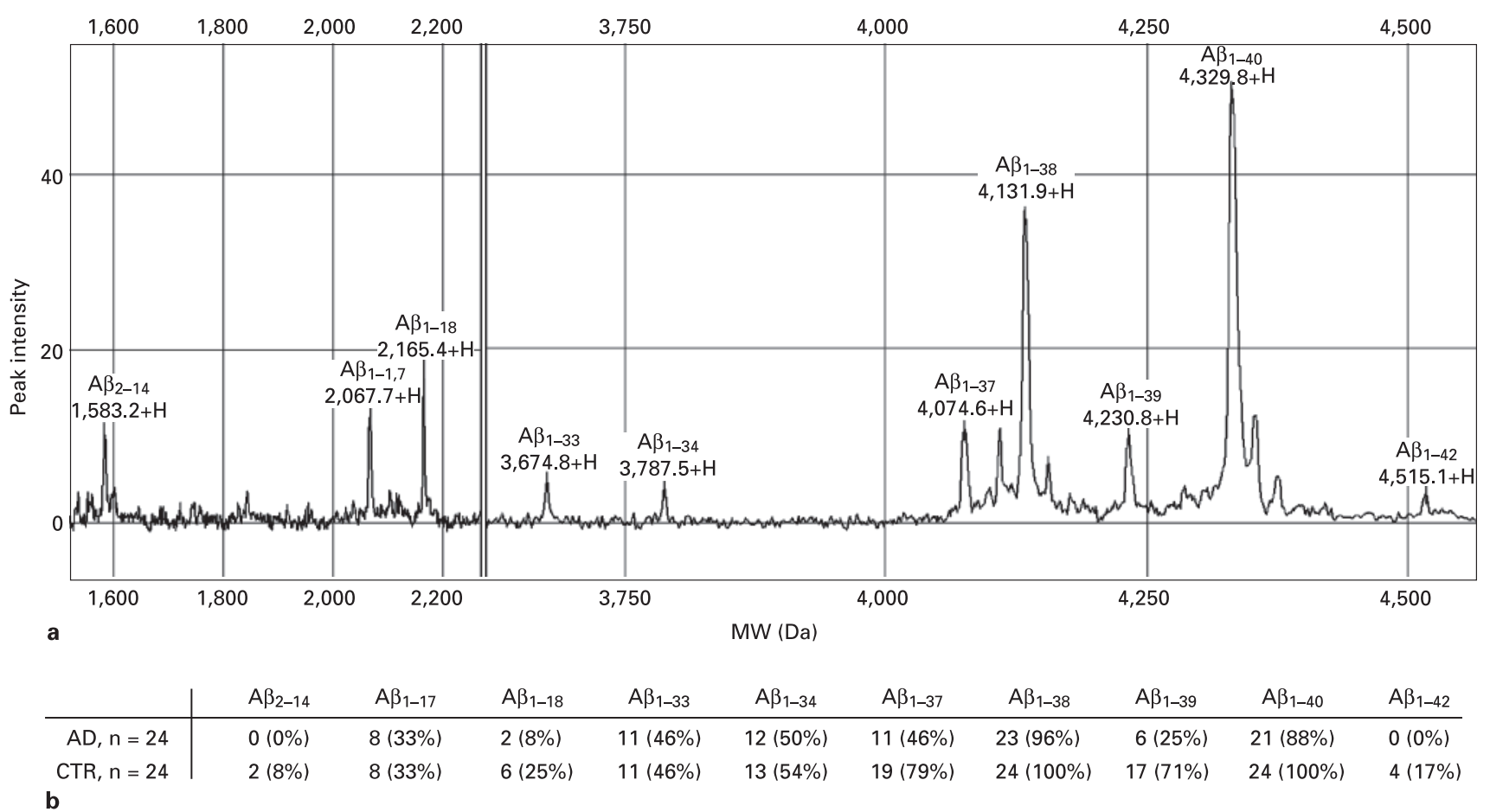

Fig. 2. a CSF profile of $A \beta$ peptides $(1$ subject) captured by monoclonal antibody $6 \mathrm{E} 10$ on a protein biochip. b Percentage of $\mathrm{A} \beta$ peptide peaks with an $\mathrm{S} / \mathrm{N}$ ratio higher than 2.5 .

Table 1. CSF A $\beta$ peptides captured by monoclonal $6 \mathrm{E} 10$ antibody

\begin{tabular}{lllll}
\hline $\begin{array}{l}\text { A } \beta \\
\text { peptides }\end{array}$ & $\begin{array}{l}\text { Mean MW } \\
\text { observed, Da }\end{array}$ & $\begin{array}{l}\text { SD } \\
\text { Da }\end{array}$ & $\begin{array}{l}\text { MW calculated } \\
\text { Da }\end{array}$ & \begin{tabular}{l} 
Amino acid sequence \\
\hline $2-14$
\end{tabular} \\
\hline 17 & $1,583.3$ & 0.08 & $1,583.6$ & AEFRHDSGYEVHH \\
18 & $2,068.5$ & 0.69 & $2,068.2$ & DAEFRHDSGYEVHHQKL \\
33 & $3,166.4$ & 0.65 & $2,167.3$ & DAEFRHDSGYEVHHQKLV \\
34 & $3,789.4$ & 0.89 & $3,674.0$ & DAEFRHDSGYEVHHQKLVFFAEDVGSNKGAIIG \\
37 & $4,076.9$ & 0.85 & $3,787.2$ & DAEFRHDSGYEVHHQKLVFFAEDVGSNKGAIIGL \\
38 & $4,134.0$ & 1.00 & $4,074.5$ & DAEFRHDSGYEVHHQKLVFFAEDVGSNKGAIIGLMVG \\
39 & $4,233.3$ & 1.10 & $4,131.6$ & DAEFRHDSGYEVHHQKLVFFAEDVGSNKGIIGLMVGG \\
40 & $4,332.4$ & 1.00 & $4,329.9$ & DAEFRHDSGYEVHHQKLVFFAEDVGSNKGAIGLMVGGV \\
42 & $4,516.8$ & 1.63 & $4,514.1$ & DAEFRHDSGYEVHHQKLVFFAEDVGSNKGAIGLMVGGVV \\
& & & DAEFRHDSGYEVHHQKLVFFAEDVGSNKGAIGLMVGGVVIA
\end{tabular}

Mean MW with standard deviation (SD) in daltons, calculated peptide MW in daltons and amino acid sequence. Only peaks with an S/N ratio higher than 2.5 were included in the analyses. 

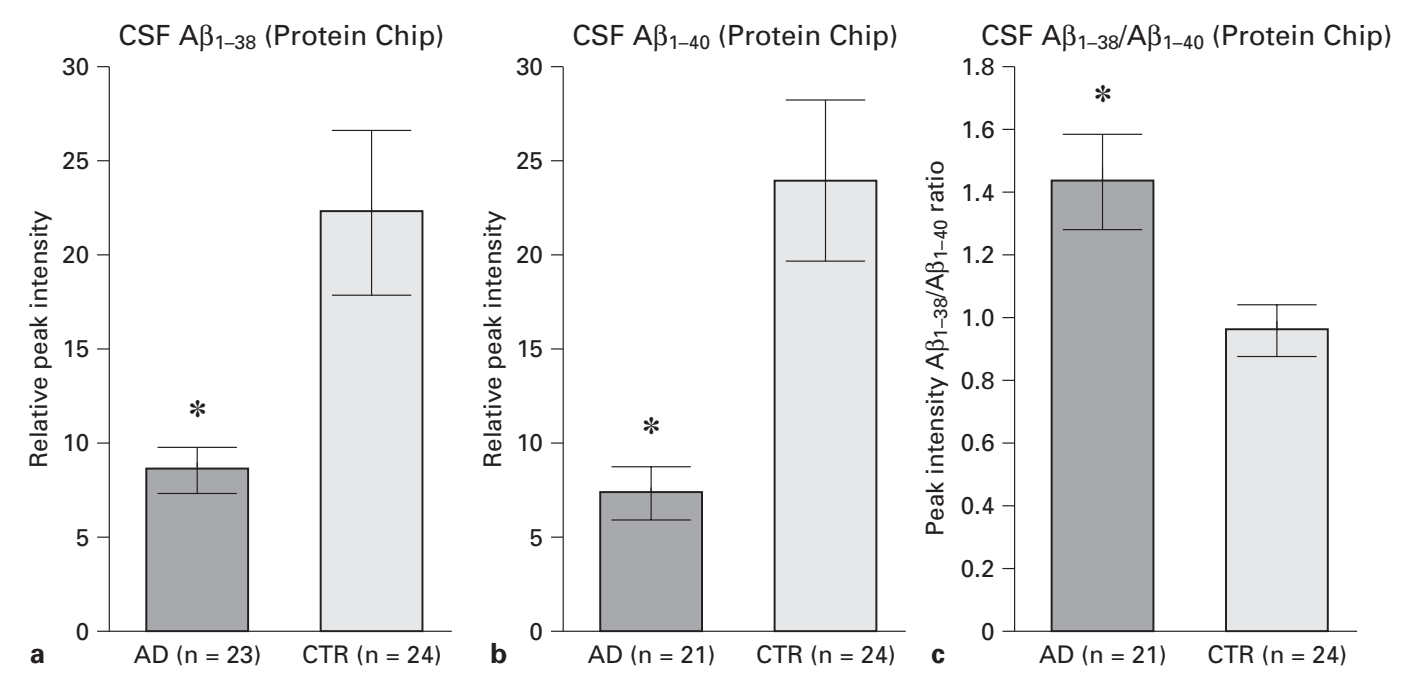

Fig. 3. $\operatorname{CSF} A \beta_{1-38}(\mathbf{a})$ and $A \beta_{1-40}$ (b) peak intensity measured on the protein biochip after normalization to a common matrix peak in patients with AD and CTR. ${ }^{*} p=0.001(\mathbf{a})$ and $* p=0.000(\mathbf{b})$, Mann-Whitney test. Only peaks with an $\mathrm{S} / \mathrm{N}$ ratio higher than 2.5 were included in calculations. $\mathbf{c}$ Mean peak intensity $\mathrm{A} \beta_{1-38} / \mathrm{A} \beta_{1-40}$ ratio in CSF of patients with AD and CTR. ${ }^{*} \mathrm{p}<0.01$, Mann-Whitney U test.

The mean peak intensity corresponding to $A \beta_{1-38}$ [mean molecular weight (MW) 4,134 Da] was lower in $\mathrm{CSF}$ of $\mathrm{AD}$ patients (mean $8.65 \pm 1.12 \mathrm{SE}, \mathrm{n}=23$ ), as compared to CTR $(22.28 \pm 4.25, \mathrm{n}=24 ; \mathrm{p}<0.01$, MannWhitney U test) (fig. 3a). Similarly, the mean peak intensity corresponding to $\mathrm{A} \beta_{1-40}$ (mean MW 4,332.4 Da) was lower in CSF of AD patients (mean 7.55 $\pm 1.18 \mathrm{SE}, \mathrm{n}=$ $21)$ as compared to CTR $(23.98 \pm 4.25, \mathrm{n}=24 ; \mathrm{p}<0.01$, Mann-Whitney U test) (fig. 3b).

The mean peak intensity of the $A \beta_{1-38} / A \beta_{1-40}$ ratio was significantly higher in CSF of the AD patients $(1.43 \pm$ $0.15 \mathrm{SE}, \mathrm{n}=21)$, as compared to CTR $(0.95 \pm 0.08, \mathrm{n}=$ 24; $p=0.01$, Mann-Whitney U test) (fig. 3c).

\section{Discussion}

We have determined mass profiles of $A \beta$ peptides in human CSF by using protein biochip technology. We found $A \beta$ species corresponding to $A \beta_{1-40}$ and $A \beta_{1-42}$ $(4,333.5$ and 4,517.7 $\mathrm{Da}$, respectively), and additionally detected $A \beta$ species corresponding to $A \beta_{2-14}, A \beta_{1-17}$, $A \beta_{1-18}, A \beta_{1-33}, A \beta_{1-34}, A \beta_{1-37}, A \beta_{1-38}$ and $A \beta_{1-39}$ in both AD patients and CTR subjects. Presence of $A \beta$ species with similar mass profiles was recently reported in cell culture media, measured by immunoprecipitation-MALDI-TOF mass-spectrometric analysis (IP/MS) [20, 21], immunoprecipitation-HPLC-mass spectrometry [22], as well as by SELDI technology [13-16]. In human CSF, several of the mass peaks found in the present analyses, including $A \beta_{1-38}$, were also identified by MALDITOF [6] and SELDI [17]. Thus, protein biochip technology may allow for detection of a heterogeneous population of truncated $A \beta$ peptides in human CSF. The exact origin of the various $A \beta$ species is currently not known; in addition to the action of the APP secretases and endopeptidases, such as IDE and neprelysin (see fig. 1), other yet unidentified proteases may be involved. Interestingly $A \beta_{1-38}$ turned out to be one of the most prominent $A \beta$ peptide in CSF, particularly in AD patients, where it showed an even higher peak intensity than $A \beta_{1-40}$. These results are in line with a recent report of increased $A \beta_{1-38}$ (in percent, relative to total $A \beta$ ) in CSF of patients with $\mathrm{AD}$, as well as chronic neuroinflammation [6].

The generation of $A \beta_{1-38}$ peptide is still a matter of discussion. Beher et al. [16] showed that such C-terminally truncated peptides are generated by action of $\gamma$-secretase and not by a separate enzyme entity. In a cell culture model, Weggen et al. [23] and De Strooper and Konig [24] also demonstrated an increase of $\mathrm{A} \beta_{1-38}$ peptides and a de- 
crease of $A \beta_{1-42}$ upon administration of nonsteroidal antiinflammatory drugs with potential $\gamma$-secretase activities.

In conclusion, protein biochip technology may allow for both mass profiling and relative quantitation of $A \beta$ species in human CSF, and may thus expand the methodological repertoire of diagnostic and therapeutic biomarker research in AD.

\section{Acknowledgments}

We thank Lee Lomas and Pia Nybom for technical support and installation of the SELDI protein biochip system (Ciphergen), Andrea Walter, Estelle Obrist, Christin Wilde and Esmeralda Garcia for expert technical assistance, and Jay Tracy for editing the manuscript. This work was supported by NCCR on Neuronal Plasticity and Repair, and the European Union under the programme 'Quality of Life and Management of Living Resources', Key Action 3 'The Cell Factory', Contract No. QLK3-CT-2001-02362.

\section{References}

$>1$ Jarrett JT, Berger EP, Lansbury PT Jr: The carboxy terminus of the beta amyloid protein is critical for the seeding of amyloid formation: Implications for the pathogenesis of Alzheimer's disease. Biochemistry 1993;32:46934697.

2 Iwatsubo T, Odaka A, Suzuki N, Mizusawa H, Nukina N, Ihara Y: Visualization of A beta 42(43) and A beta 40 in senile plaques with end-specific A beta monoclonals: Evidence that an initially deposited species is A beta 42(43). Neuron 1994;13/1:45-53.

-3 Gravina SA, Ho L, Eckman CB, et al: Amyloid beta protein (A beta) in Alzheimer's disease brain. Biochemical and immunocytochemical analysis with antibodies specific for forms ending at A beta 40 or A beta 42(43). J Biol Chem 1995;270:7013-7016.

$\checkmark 4$ Alonzo NC, Hyman BT, Rebeck GW, Greenberg SM: Progression of cerebral amyloid angiopathy: Accumulation of amyloid-beta40 in affected vessels. J Neuropathol Exp Neurol 1998;57:353-359.

$\checkmark 5$ Boss MA: Diagnostic approaches to Alzheimer's disease. Biochim Biophys Acta 2000; 1502:188-200.

6 Wiltfang J, Esselmann H, Bibl M, et al: Highly conserved and disease-specific patterns of carboxyterminally truncated Abeta peptides 1-37/ $38 / 39$ in addition to 1-40/42 in Alzheimer's disease and in patients with chronic neuroinflammation. J Neurochem 2002;81:481-496.

$\checkmark 7$ Shoji M, Kanai M, Matsubara E, Tomidokoro Y, Shizuka M, Ikeda Y, Ikeda M, Harigaya Y, Okamoto K, Hirai S: The levels of cerebrospinal fluid Abeta40 and Abeta42(43) are regulated age-dependently. Neurobiol Aging 2001; 22/2:209-215

8 Tapiola T, Pirttila T, Mikkonen M, et al: Three-year follow-up of cerebrospinal fluid tau, beta-amyloid 42 and 40 concentrations in Alzheimer's disease. Neurosci Lett 2000;280/2: 119-122. $\checkmark 9$ Mehta PD, Pirttila T, Mehta SP, Sersen EA, Aisen PS, Wisniewski HM: Plasma and cerebrospinal fluid levels of amyloid beta proteins 1-40 and 1-42 in Alzheimer disease. Arch Neurol 2000;57/1:100-105.

10 Fukuyama R, Mizuno T, Mori S, Nakajima K, Fushiki S, Yanagisawa K: Age-dependent change in the levels of Abeta40 and Abeta42 in cerebrospinal fluid from control subjects, and a decrease in the ratio of Abeta42 to Abeta40 level in cerebrospinal fluid from Alzheimer's disease patients. Eur Neurol 2000;43/3:155-160.

11 Jensen M, Schroder J, Blomberg M, Engvall B, Pantel J, Ida N, Basun H, Wahlund LO, Werle E, Jauss M, Beyreuther K, Lannfelt L, Hartmann T: Cerebrospinal fluid A beta42 is increased early in sporadic Alzheimer's disease and declines with disease progression. Ann Neurol 1999;45:504-511.

12 Kanai M, Matsubara E, Isoe K, Urakami K, Nakashima K, Arai H, Sasaki H, Abe K, Iwatsubo T, Kosaka T, Watanabe M, Tomidokoro Y, Shizuka M, Mizushima K, Nakamura T, Igeta Y, Ikeda Y, Amari M, Kawarabayashi T, Ishiguro K, Harigaya Y, Wakabayashi K, Okamoto K, Hirai S, Shoji M: Longitudinal study of cerebrospinal fluid levels of tau, A beta 1-40, and A beta1-42(43) in Alzheimer's disease: A study in Japan. Ann Neurol 1998;44/1:17-26.

13 Davies H, Lomas L, Austen B: Profiling of amyloid beta peptide variants using SELDI Protein Chip arrays. Biotechniques 1999;27: 1258-1261.

14 Frears ER, Stephens DJ, Walters CE, Davies $\mathrm{H}$, Austen BM: The role of cholesterol in the biosynthesis of beta-amyloid. Neuroreport 1999;10:1699-1705.

15 Austen BM, Frears ER, Davies H: The use of seldi proteinchip arrays to monitor production of Alzheimer's betaamyloid in transfected cells. J Pept Sci 2000;6:459-469.

16 Beher D, Wrigley JD, Owens AP, Shearman MS: Generation of C-terminally truncated amyloid-beta peptides is dependent on gammasecretase activity. J Neurochem 2002;82:563575 .
7 Lewczuk P, Esselmann H, Meyer M, Wollscheid V, Neumann M, Otto M, Maler JM, Ruther E, Kornhuber J, Wiltfang J: The amyloid-beta (Abeta) peptide pattern in cerebrospinal fluid in Alzheimer's disease: Evidence of a novel carboxyterminally elongated Abeta peptide. Rapid Commun Mass Spectrom 2003;17: 1291-1296.

18 McKhann G, Drachman D, Folstein M, Katzman R, Price D, Stadlan EM: Clinical diagnosis of Alzheimer's disease: Report of the NINCDS-ADRDA Work Group under the auspices of Department of Health and Human Services Task Force on Alzheimer's Disease. Neurology 1984;34:939-944.

19 World Health Organization G: ICD-10: The International Statistical Classification of Diseases and Related Health Problems, 10th revision. Geneva, World Health Organization, 1993.

20 Wang R, Sweeney D, Gandy SE, Sisodia SS: The profile of soluble amyloid beta protein in cultured cell media. Detection and quantification of amyloid beta protein and variants by immunoprecipitation-mass spectrometry. J Biol Chem 1996;271:31894-31902.

21 Kametani F, Nakamura Y, Tanaka K, Hashimoto R, Takeda M: Semiquantitative analysis of amyloid beta peptides using a combination of immunoprecipitation and matrix-assisted laser desorption ionization/time-of-flight-mass spectrometry. Anal Biochem 1999;275/2:262265.

22 Clarke NJ, Tomlinson AJ, Ohyagi Y, Younkin S, Naylor S: Detection and quantitation of cellularly derived amyloid beta peptides by immunoprecipitation-HPLC-MS. FEBS Lett 1998;430:419-423.

23 Weggen S, Eriksen JL, Das P, et al: A subset of NSAIDs lower amyloidogenic Abeta42 independently of cyclooxygenase activity. Nature 2001;414:212-216.

24 De Strooper B, Konig G: An inflammatory drug prospect. Nature 2001;414:159-160. 